\title{
CONSTITUTIONAL CHANGE: TOWARDS BETTER HUMAN RIGHTS PROTECTION IN Australia
}

\author{
Mohammad Ibrahim* \\ Faculty of Law, Gadjah Mada University \\ mohammadibrahim@ugm.ac.id
}

\begin{abstract}
Many legal scholars contend that Australia does not have a charter of rights in its Constitution. The legal scholar Rosalind Dixon, however, suggests that the Constitution does include some provisions that could be viewed as resembling a (partial) bill of rights. This constitutional framework might cause one to ponder whether human rights are adequately protected in the Australian constitutional system. This paper attempts to consider this question. It is argued that the protection of human rights under the Constitution, federal and state laws is not fully capable of responding to at least three human rights crises presented. Accordingly, the paper suggests that Australia should consider the idea of amending the Constitution in order to better human rights protection in the country. It offers suggestion that the Canadian model protection of human rights could be considered as one of the primary sources for reforms in the future.
\end{abstract}

Keywords: Australia, Canada, Constitutional Amendment, Human Rights.

\section{INTRODUCTION}

It is frequently asserted that Australia is one of the few countries in the world that does not have a bill of rights in its constitution nor does it have

\footnotetext{
Lecturer in Law at the Faculty of Law, Universitas Gadjah Mada. The author wishes to thank Claire Kaylock, Vanessa Leak and the anonymous reviewers for their helpful comments on earlier drafts. Any errors or shortcomings are my own.
} 
an enumerated list of rights in its federal legislation. ${ }^{1}$ This assertion, however, has been described as an orthodox view given that Australia actually does have a sort of charter of rights which is quite narrow compared to international standards. ${ }^{2}$ Indeed, a recent comparison study has suggested that while the average number of Universal Declaration of Human Rights ('UDHR') provisions contained in constitutions around the world is thirty-five, there are only six provisions in the Australian Constitution that are similar to UDHR provisions. ${ }^{3}$ As such, one might be forgiven to question whether the Australian Constitution provides adequate protection of human rights.

In the federal level, the Commonwealth Parliament adopted a new model of rights protection by enacting the Human Rights (Parliamentary Scrutiny) Act 2011 (Cth). ${ }^{4}$ This statutory framework gives a greater role on the part of the Parliament through Parliamentary Joint Committee on Human Rights (PJCHR) in ensuring the compatibility of Bills of Acts and legislative instruments with human rights. ${ }^{5}$ Before this, in 1986 the Parliament also established an Australian Human Rights Commission which is tasked to run several functions under antidiscrimination and human rights laws established by the Parliament. ${ }^{6}$ In the state level, at least two state parliaments, the Australian Capital Territory (ACT) Legislative Assembly and the Victorian Parliament have decided to adopt the dialogue model in providing human rights protection by enacting the Human Rights Act $2004(\mathrm{ACT})^{7}$ and the Charter of Human Rights and Responsibilities Act 2006 (Vic). ${ }^{8}$

\footnotetext{
See, for example, Robert French, "Protecting Human Rights Without a Bill of Rights," The John Marshall Law Review 43, no. 3 (Spring 2010): 769; Michael Kirby, "Protecting Human Rights in Australia without a Charter," Commonwealth Law Bulletin 37, no.2 (June 2011): 255; Susan Crennan, "Magna Carta, Common Law Values and the Constitution," Melbourne University Law Review 39, no.1 (2015): 340.

2 Rosalind Dixon, "An Australian (Partial) Bill of Rights," International Journal of Constitutional Law 14, no. 1 (January 2016): 81.

3 Colin J Beck et al, "Constitutions in World Society: A New Measure of Human Rights" (January 2017): 11, http:// dx.doi.org/10.2139/ssrn.2906946.

Human Rights (Parliamentary Scrutiny) Act 2011 (Cth).

5 Ibid.

6 "Functions of the Australian Human Rights Commission," Australian Human Rights Commission, last accessed February 15, 2019, https://www.humanrights.gov.au/about/functions-australian-human-rights-commission. Human Rights Act 2004 (ACT).

8 Charter of Human Rights and Responsibilities Act 2006 (Vic).
} 
This paper seeks to examine whether the Constitution along with the existing laws are effective in protecting human rights in Australia. It does this by first exploring the brief history of the formation of the Australian constitution which leads to narrow rights being expressed in the constitution as well as the emergence of implied rights in Part II. Afterward, it outlines the protection of human rights under federal and state laws before assessing the efficacy of rights protection performed by the PJCHR. In Part III, it explains why Australia needs a constitutional amendment to better its rights protection despite the fact that countries with bills of rights in their constitution are not necessarily more free than Australia. In Part IV, it suggests that Australia should adopt the Canadian model protection of human rights by extending the rights provisions in the Constitution. It is argued that doing so would serve as a stronger human rights protection mechanism.

\section{HOW DOES RIGHTS PROTECTION WORK IN AUSTRALIA?}

\subsection{Human Rights in Drafting the Constitution}

In formulating the Australian Constitution that took place in successive conventions, it can be said that the founding fathers made considerable reference to the Constitution of the United States. ${ }^{9}$ However, the influence of the American Constitution that bolster the desire to incorporate an extensive list of rights into the constitution did not receive a welcome reception from the leading colonial citizens..$^{10}$ At the 1898 Melbourne Convention, for example, the proposal of the Attorney General for Tasmania, Andrew Inglis Clark, to guarantee equal protection before the law was rejected by votes of twenty-three to nineteen. ${ }^{11}$ It is believed that there were two primary considerations that led to the rejection of the proposal which was based on the Fourteenth Amendments of the US Constitution. ${ }^{12}$

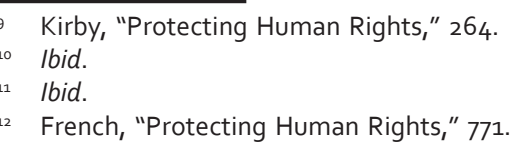


First, there was a concern that the equal rights protection would affect the states' legislative powers. ${ }^{13}$ The opposition of the proposal argued that the recognition of equal rights protection could potentially keep states from regulating the employment of Asian workers. ${ }^{14}$ In fact, more specifically, Isaac Isaacs, who later became the Chief Justice of the High Court of Australia, contested the anti-discrimination proposal on the footing that it would strike down laws that exclude Asian and African mining workers. ${ }^{15}$ As explained by Robert French, Former Chief Justice of High Court of Australia, during the making of the constitution and even long after the federation, Western Australian had racially biased immigration laws and other laws that kept persons with Asian and African descent from mining on a goldfield. ${ }^{16}$

Secondly, it was contended that such right protection was unnecessary to be inserted in the Australian Constitution. ${ }^{17}$ This was so because the Fourteenth Amendment occurred primarily to ensure that there would be no deprivation of African-American rights in the wake of the civil war. ${ }^{18}$ From this line of thought, Australia would not have a civil war over racial matter such as that which occurred in the United States because there were not much people of colour in the country. Accordingly, the opponent of the equal rights protection proposal was definitive that there was no need to insert a provision forbidding discrimination against people on the ground of their race in Australia. ${ }^{19}$

Notwithstanding the foregoing, the other proposals in regard to certain rights advanced by Clark were successfully inserted into the final draft. Those are trial by jury (s8o), the prohibition on the Commonwealth making laws in respect of religion (s116), and the protection of discrimination based on residence (s117)..$^{20}$ The insertion of such rights into the Constitution does not

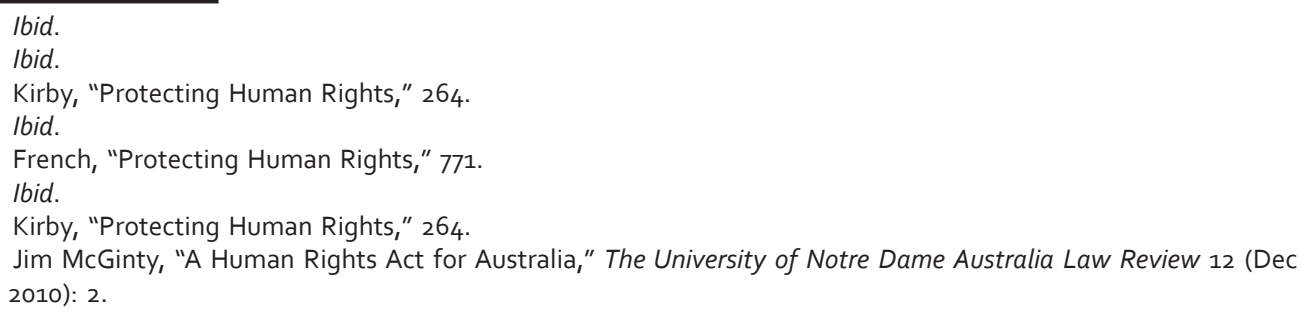


preclude the founding fathers from being criticised. Indeed, there has been a sharp criticism that the drafters of the constitution had an intention to discriminate and to disrespect human rights. ${ }^{21}$ The intention of the framers of the Constitution turned out to have adversely affected those who were seen as undesirable. At least two actions demonstrated this.

First, the Constitution did not recognise the existence of Indigenous Australians and their citizenship. ${ }^{22}$ It was not until 1967 when the amendment of the constitution repealed the discriminatory clauses laid down in s51 xxvi and s127..$^{23}$ Indeed, it was the decision of the High Court of Australia through Mabo vs Queensland that corrected the misinterpretation of the common law doctrine of terra nullius, which for a long time kept Indigenous Australians such as Merriam people from having legal entitlement to land. ${ }^{24}$ Through this decision, the Merriam people were declared entitled "as against the whole world to possession, occupation, use and enjoyment of the island". ${ }^{25}$

Second, the Commonwealth Parliament, at the outset of its work, enacted the Immigration Restriction Act 1901 to place restrictions on immigration and to provide for the removal from the Commonwealth of prohibited immigrants. ${ }^{26}$ This legislation later became a precursor of the White Australia Policy, which imposed certain criteria to exclude non-white Europeans to migrate to Australia. ${ }^{27}$ While many, perhaps, did not want to admit that there was a racial prejudice in the policy, it was clear that the non-European policy allowed, for instance, immigration officers to interpret the true skin colour of those who might wish to migrate to Commonwealth of Australia. ${ }^{28}$ Based on this criterion, then, the immigration officers would determine whether the applicants are suitable to migrate. With respect to

3 French, "Protecting Human Rights," 774.

24 Barbara Hocking, "Aboriginal Law Does Now Run in Australia-Reflections on the Mabo Case: From Cooper v. Stuart through Milirrpum to Mabo," Sydney Law Review 15 (1993): 205.

25 Mabo v Queensland (1992) 175 CLR 1.

6 Immigration Restriction Act 1901 (Cth).

27 McGinty, "A Human Rights," 3.

8 NFSA Films, "Admission Impossible," filmed in 1992 in Australia, video, 54:22, https://www.youtube.com/ watch?v=uPfJRetYPo4. 
the Constitution, however, it does not only protect rights that are expressly stated, but also those that are not clearly outlined in the Constitution as will be explained briefly below.

\subsection{Express and Implied Rights in the Constitution}

\subsubsection{Express Rights}

The express rights are the rights that are clearly stated in the Australian Constitution. These rights are extremely narrow, comprising of only three political and civil rights and two economic rights. ${ }^{29}$ Cheryl Saunders describes these constitutional rights as rights-type provisions because these clauses seem to place restrictions on the Commonwealth power as opposed to giving positive rights to individuals..$^{30}$ With respect to the lack of rights recognition in the Constitution, George Williams suggests that this was the result of the framers of the Constitution being influenced by English legal scholars such as Dicey and Bryce who did not see the need to include rights in written constitutions. ${ }^{31}$

As previously stated, there are three political and civil rights enshrined in the Constitution. Firstly, trial by jury which is guaranteed in s8o. More specifically, however, the guarantee only applies to 'indictable' offences under federal laws. ${ }^{32}$ In other words, this section would not apply if the state legislation declared that an offense is not to be tried on indictment. Secondly, religious freedom as laid down in s116. Although this section forbids the Commonwealth Parliament from making laws that would establish a national religion or impedes individuals from exercising their religion or imposes any religious observance, this section does not apply to state laws either. ${ }^{33}$ In relation to s8o and s116, The High Court has also been criticised for interpreting the provision too narrowly. For example, in

McGinty, "A Human Rights," 6.

Cheryl Saunders, "The Australian Constitution and Our Rights," in Future Justice (Sydney: Future Leaders, 2010), 120.

French, "Protecting Human Rights," 774.

Saunders, "The Australian Constitution," 121.

Ibid. 
Adelaide Company of Jehovah's Witnesses Inc $v$ Commonwealth, the High Court held that s116 allowed laws prohibiting advocacy detrimental to the prosecution of war by the Commonwealth. ${ }^{34}$ Thirdly, the right not to be discriminated based on state residence as stated in s117. This provision has been considered as worthy but not having a significant practical use due to the rarity of the discrimination. ${ }^{35}$

The economic rights in the constitution consist of some protection related to property rights ( $\mathrm{s}_{51} \mathrm{xxxi}$ ) and the right to interstate trade (s92). While the former requires the Commonwealth authority to provide 'just terms' in the acquisition of property, the latter guarantees free market access between states. ${ }^{36}$ In contrast with the narrow interpretation of political and civil rights, the High Court has construed these provisions broadly, giving a wider operative space allowing economic rights to develop. ${ }^{37}$ For example, in Betfair Pty Limited $v$ Western Australia, the High Court held that the amendments to the Betting Control Act, which placed new restrictions on Betfair were found to have contravened section 92 of the Constitution since, among other things, the prohibition of betting constituted a discriminatory burden on interstate trading. ${ }^{38}$ Moreover, in Minister of Army $v$ Dalzie, the High Court appeared to have taken a wide view of the concept of property in interpreting 551 xxxi of the Constitution, as it took the view that property means "...any tangible or intangible thing which the law protects under the name of property". 39

\subsubsection{Implied Rights}

Unlike express rights which are clearly set out in the Constitution, implied rights are the outcome of a judicial interpretation method namely 'implication from text and structure'. $4^{\circ}$ The implied rights can be divided into

34 Adrienne Stone, "Australia's Constitutional Rights and the Problem of Interpretive Disagreement," Sydney Law Review 27, no. 1 (2005): 32.

5 McGinty, "A Human Rights," 8.

6 Ibid.

Stone, "Australia's Constitutional Rights," 32.

Betfair Pty Limited v Western Australia (2008) 234 CLR 418.

Minister of Army v Dalziel (1944) 68 CLR 261.

Stone, "Australia's Constitutional Rights," 32. 
two categories. The first rights category is derived from the implication of the provisions establishing the Parliament and the Government. ${ }^{41}$ For instance, through a series of decisions in 30 years, the High Court has held in Lange $v A B C^{42}$ that there exists an implied freedom of political communication. ${ }^{43}$ It has been established that the implied freedom of political communication was the source of the common law in order that federal and state laws adhere to it. Additionally, in Roach $v$ Electoral Commissioner, ${ }^{44}$ the Court invalidated federal law provisions which purported to take away the rights of prisoners to vote. In making its judgment, the Court relied upon section 24 that requires Members of the House of Representative to be directly elected by the people. ${ }^{45}$

The second rights category is implied from the provisions that establish the power of the judiciary. The implied rights were conferred on individuals based on Chapter III of the Constitution which values the independence and the impartiality of the court. ${ }^{46}$ In several cases, the High Court has found that the Constitution provides some rights protection so as to ensure the integrity of the judicial system. In Kable v Director of Public Prosecutions, ${ }^{47}$ for example, the court held that the NSW legislation regulating preventive detention was invalid on the basis that the state Parliament was prohibited under Chapter III of the Constitution to confer power on state courts..$^{48}$

Despite recognition of implied rights, some commentators have expressed concerns relating to the exercise of this judicial interpretation and the scope of the implied rights. The High Court has been accused of engaging in judicial activism and undermining the rule of law for continuingly discovering implied rights and striking down the social policy enacted by

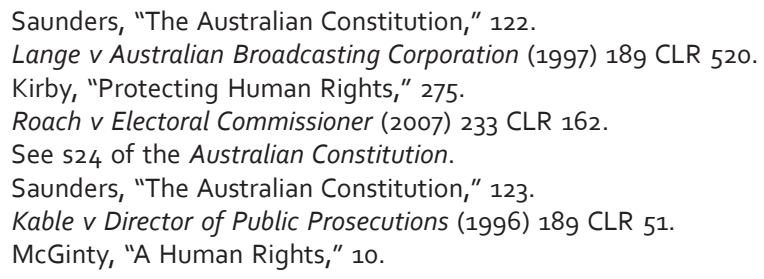


the democratic institution. ${ }^{49}$ On the contrary, there has been a concern on the extent to which the protection given to the implied rights is unclear..$^{50}$ One, for example, might question whether Australia protects freedom of speech and freedom of the press considering that there is no clear provision stating that in the Constitution. Nor is there a legal principle to refer in order to determine, for example, the limit of the speech that is permitted under the Constitution.

\subsection{Commonwealth Legislation Protection}

It is probably fair to say that the rights protection under federal legislations is more certain and more applicable than the rights protected under the Constitution. Take, for example, the Racial Discrimination Act 1975 (Cth) (RDA) ${ }^{51}$ upon which the High Court relied on to resolve issues in Mabo v Queensland..$^{22}$ In this case, the court struck down the Queensland Coast Islands Declaratory Act 1985 (Qld) purporting to eliminate the native title of Murray Islanders due to its incompatibility with the RDA. Besides introducing anti-race discrimination law, the Commonwealth Parliament has also passed legislations that prohibit discrimination on the grounds of sex, ${ }^{53}$ disability ${ }^{54}$ and age..$^{55}$

Moreover, through the Australian Human Rights Commission Act 1986 (Cth), as the name suggests, an Australian Human Rights Commission has been established. ${ }^{6}$ Pursuant to the Australian Human Rights Commission Act 1986 (Cth) as well as anti-discrimination federal laws, the Commission is tasked with:

- investigating and conciliating complaints of discrimination or breaches of human rights;

\footnotetext{
James Allan, "The Three Rs of Recent Australian Judicial Activism: Roach, Rowe and (No)'Riginalism," Melbourne University Law Review 36, no. 2 (2012): 777-782.

Saunders, "The Australian Constitution," 124.

Racial Discrimination Act 1975 (Cth).

Mabo v Queensland (1988) 166 CLR 186.w

Sex Discrimination Act 1984 (Cth).

Disability Discrimination Act 1992 (Cth).

Age Discrimination Act 2004 (Cth).

History of the Commission, Australian Human Rights Commission, https://www.humanrights.gov.au/about/whatare-human-rights/history-commission.
} 
- holding public inquiries into human rights issues of national importance and making recommendations to address discrimination and breaches of human rights;

- developing human rights education programs and resources for schools, workplaces and the community;

- providing independent legal advice to assist courts in cases that involve human rights principles;

- providing advice and submissions to parliaments and governments to develop laws, policies and programs consistent with existing national laws and international human rights agreements;

- undertaking and coordinating research into human rights and discrimination issues. 57

The rights protection under Commonwealth statutory has been described as more straightforward. $5^{8}$ This is so because the Commonwealth Parliament has given legal recognition of the rights that can be effectively enforced throughout the country. ${ }^{99}$ Such protection, nevertheless, is still being criticised for covering limited rights. ${ }^{60}$ Furthermore, the limited power conferred upon the Australian Human Rights Commission indicates that the Commission would be incapable of providing effective remedies if human rights were breached by the Commonwealth power. ${ }^{61}$

\subsection{State and Territory Rights Protection}

The statutory protection of human rights has been initiated in ACT and the State of Victoria ('Victoria') with the inspiration from the United Kingdom's 'dialogue model' ${ }^{62}$ In ACT, the Legislative Assembly passed the Human Rights Act 2004 (ACT), which does not only recognise civil and political rights, but also respects economic, social, and cultural rights. In

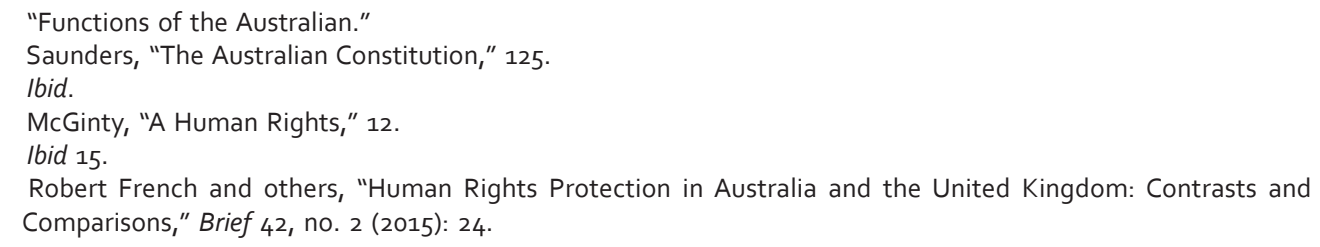


the last regard, they are translated into the right to education. ${ }^{63}$ Similarly, but not exactly, the Victorian Parliament enacted the Charter of Human Rights and Responsibilities Act 2006 (Vic), giving statutory recognition to various civil and political rights. ${ }^{64}$ Considering the reluctant attitude towards the notion of establishing a bill of rights by way of Constitution or federal legislation, the adoption of these human rights acts has been regarded as an achievement. ${ }^{65}$

Both of those acts require a new bill to be accompanied by a statement of compatibility. If a bill were found to be incompatible with human rights, the extent to which the incompatibility of the bill with human rights should be outlined. ${ }^{66}$ Irrespective of such requirement, the declaration of incompatibility does not impact on the validity and operation of the law. ${ }^{67}$ It is also worthy to note that the Victorian Charter has given power to the Supreme Court of Victoria to interpret legislation in accordance with human rights as well as declaring whether legislation is inconsistent with human rights although it does not have an authority to strike down the law. ${ }^{68}$

In terms of the advantages of this type of rights protection, several observations are worth pointing out. Firstly, unlike the other federal, state and territory legislations which offer limited rights protection, the model adopted by the ACT and Victoria has enumerated an extensive list of protected rights. ${ }^{69}$ Secondly, it is not at odds with the supremacy of Parliament. Rather, it aims to bring about consistency between legislative or executive action and fundamental human rights by fostering dialogue between arms of governments. ${ }^{70}$ Finally, and perhaps most importantly,

3 Part 3A of the Human Rights Act 2004 (ACT).

64 Part 2 of the Charter of Human Rights and Responsibilities Act 2006 (Vic).

65 See, for example, Helen Watchirs and Gabrielle McKinnon, "Five Years' Experience of the Human Rights Act 2004 (ACT): Insights for Human Rights Protection in Australia," University of New South Wales Law Journal 33(1) (2010): 136; Saunders, "The Australian Constitution," 133.

66 See s28 and s29 of the Charter of Human Rights and Responsibilities Act 2006 (VIC); s32 and s33 of the Human Rights Act 2004 (ACT).

67 Ibid.

68 See s32 and s36 of the Charter of Human Rights and Responsibilities Act 2006 (VIC).

69 McGinty, "A Human Rights," 13.

70 George Williams, "The Victorian Charter of Human Rights and Responsibilities: Origins and Scope," Melbourne University Law Review 30, no. 3 (2006): 901. 
this dialogue model of human rights protection puts a great stress on ensuring that the human rights principles are taken into consideration at the beginning of the legal and policy making processes. ${ }^{71}$

The rights protection model introduced in ACT and Victoria has also obtained various responses. There is, for instance, one recommendation to improve the statutes by expressly stating non-derogable rights such as the right against torture in the Act. ${ }^{72}$ Other has criticised the establishment of human rights acts for it would give a greater role on the part of unelected lawyers and unelected judges in public policy making. ${ }^{73}$ More importantly, the High Court has delivered a decision in Momcilovic $v$ The Queen, ${ }^{74}$ in which it addressed the question of whether the involvement of a court in rights protection under the dialogue model is consistent with the principle of separation of powers. ${ }^{75}$

The majority of the court held that the power of a state court to interpret legislation in accordance with human rights as laid out in s32 of the Victorian Charter was valid..$^{6}$ Although the majority of the court also ruled that the power conferred upon a state court to declare the incompatibility of legislation as laid out in s36 was valid, it held that such power was not within the exercise of the judiciary. ${ }^{77}$ This was so due to the characteristic of such declaration which is resembling an advisory opinion and non-binding in nature. ${ }^{78}$ Interestingly, the ruling of the court has also come to be viewed as the High Court's suggestion that the dialogue model of human rights in Victoria cannot be applied at the federal level. ${ }^{79}$ It is

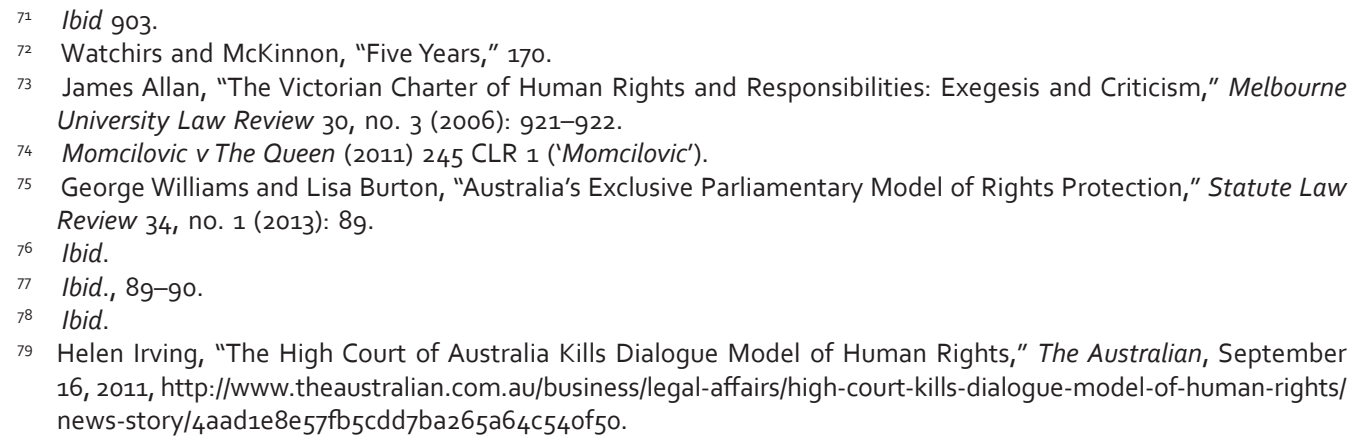
16, 2011, http://www.theaustralian.com.au/business/legal-affairs/high-court-kills-dialogue-model-of-human-rights/ news-story/4aadie8e57fb5cdd7ba265a64c540f50. 
believed that adopting the dialogue model at the federal level would breach the separation of powers. ${ }^{80}$

\subsection{Rights Protection Under the Human Rights (Parliamentary Scrutiny)} Act 2011

The adoption of Victorian Charter and Human Rights Act in Victoria and ACT has encouraged other governmental entities to inquire as to whether they should do likewise. ${ }^{81}$ In fact, the Federal Government began to grapple with the question of how human rights in Australia should be protected..$^{82}$ As a result, an Australian National Human Rights Consultation Committee was established in order to investigate the adequacy of human rights protection at the national level and find measures to better the current system. ${ }^{8}{ }_{3}$ After conducting the federal inquiry for a year, the Committee recommended in its report, among other things, that Australia should adopt the dialogue model of human rights protection, which had been earlier introduced in ACT and Victoria. ${ }^{84}$

The Government, however, rejected the recommendation and instead proposed a somewhat different model which was called 'Australia's Human Rights Framework'. ${ }^{85}$ It excluded the insertion of a charter of rights into the proposed legislation because there was a concern that that would be politically divisive. ${ }^{86}$ In 2011, the Commonwealth Parliament passed the proposed legislation. Therefore, the Human Rights (Parliamentary Scrutiny) Act 2011 (Cth) ('HRPS Act') came into force. It is worthy to note two distinctive features of rights protection model under the legislation. First, the statute established the Parliamentary Joint Committee on Human Rights ('PJCHR') tasked to examine and report the compatibility of a proposed legislation and legislative instruments with human rights. ${ }^{87}$ Secondly, the

\footnotetext{
Fiona Chong, "Human rights vs the High Court: how far can a Charter go?" Analysis \& Policy Observatory, November 23, 2011, http://apo.org.au/node/27269.

Saunders, "The Australian Constitution," 133.

82 Ibid.

3 Ibid.

84 French and others, "Human Rights Protection," 2.

Ibid.

Williams and Burton, "Australia's Exclusive," 71.

Human Rights (Parliamentary Scrutiny) Act 2011 (Cth) 57.
} 
HRPS Act also requires a proposed legislation and legislative instruments to be accompanied by a statement of compatibility ('SOC'). ${ }^{88}$ Nevertheless, there would be no effect on the validity and the enforceability of the legislation if the requirement were not met. ${ }^{89}$

The Australia's Human Rights Framework is a unique model of rights protection. It can be assumed that this current framework is similar to the UK's model that has been adopted in ACT and Victoria. But this assumption is not completely true because the Australia's model does not give the role to the courts to interpret legislation in accordance with human rights nor to make a declaration of incompatibility such as in the UK..$^{\circ 0}$ Another exceptional element from this 'exclusive parliamentary model' is that there is not an extensive list of rights outlined in the statutory framework. ${ }^{91}$ The statute instead defines human rights as 'the rights and freedoms recognised and declared by' one of the seven international treaties to which Australia is a party. ${ }^{92}$ Despite this, the HRPS Act has been referred to as a welcome development as it confirms the commitment of the Commonwealth to comply with its international obligation. ${ }^{93}$

With respect to the effectiveness of the exclusive parliamentary model drawing from the statutory framework, some commentators doubt that the current model would bring about strong protection regime of human rights. George Williams and Lisa Burton, for instance, point out at least two pertinent concerns. The first concern relates to the way in which rights defined in the HRPS Act. ${ }^{94}$ It has been suggested that the absence of an enumerated list of rights against which the SOC is examined, will likely to affect the clarity of analysis made by the PJCHR. ${ }^{95}$ The second concern is associated with the lack of legal consequence if Parliamentarians do not

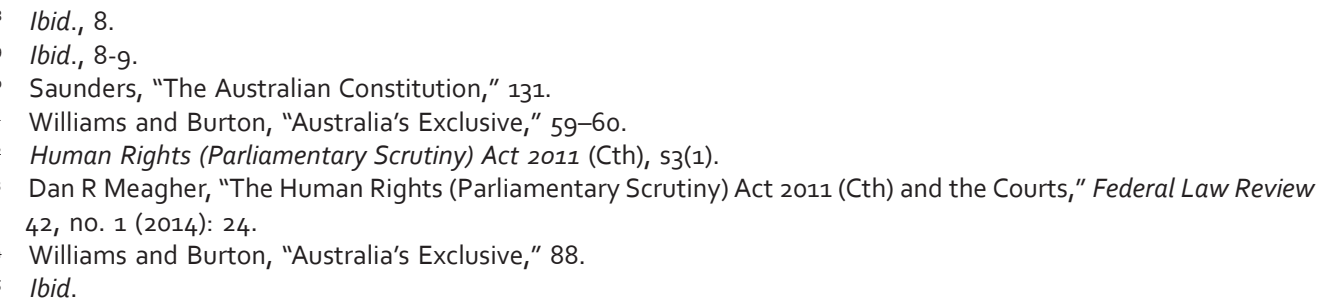


comply with the requirement to pass a bill with a SOC nor consider the PJCHR's report. ${ }^{96}$ Further, they opine that even if these two problematic features have been addressed, there is no guarantee that the Parliament will abide by the scrutiny regime in view of the absence of independent judicial supervision. ${ }^{97}$

Additionally, there have been attempts to assess the operation of the exclusive parliamentary model. One study found that the Parliamentarians and the Government Officials have failed to fulfil their obligation adequately..$^{8}$ In part this is due to the lack of rights literacy of government departments and in part because of no sanctions provided for failing to comply with the HRPS Act. ${ }^{99}$ In a more recent study, a more comprehensive approach has been conducted to evaluate the operation and the impact of the current rights protection regime in the span of four years since its operation. ${ }^{100}$ One of the key findings was that almost three-fourths of the PJCHR's reports, which indicated that proposed legislations were potentially incompatible with human rights, did not have any effect at all to the outcome of the proposed legislations. ${ }^{101}$ This was so mainly because of the delay of the PJCHR's report being delivered. ${ }^{102}$ Further, it reinforced the need for judicial involvement in the current regime to supervise the compliance of the branches of the government with their responsibility. ${ }^{103}$

\section{THE NEED FOR CONSTITUTIONAL AMENDMENT}

It has been explained that the Constitution only provides very limited rights protection in the forms of express rights and implied rights. But introducing broader rights by way of either constitutional change or federal legislation may

96 Ibid., 90.

97 Ibid., 91-92.

98 Shawn Rajanayagam, "Does Parliament Do Enough: Evaluating Statements of Compatibility under the Human Rights (Parliamentary Scrutiny) Act," University New South Wales Law Journal 38, no. 3 (2015): 1046.

99 Ibid., 1076-1077.

100 George Williams and Daniel Reynolds, "The Operation and Impact of Australia's Parliamentary Scrutiny Regime for Human Rights," Monash University Law Review 41, no. 2 (2016): 469.

101 Ibid., 490.

102 Ibid.

103 Ibid., 507. 
be difficult to achieve because of the Australian political and legal culture that seems somewhat antagonistic towards the notion of a bill of rights. Indeed, history shows that the attempts to incorporate human rights into the constitution and the federal legislation have failed several times. In fact, an attempt to extend the existing rights in the Constitution such as freedom of religion, trial by jury and just terms of property acquisition was overwhelmingly rejected in the 1988 Australian referendum. ${ }^{104}$ This was so because a constitutional change is notoriously difficult to achieve due to $\$ 128$ of the Constitution which requires a double majority of states and the people. ${ }^{105}$ In addition, the efforts to introduce a charter of human rights through federal legislation seemed to always lead to the similar outcome. Two initiatives to make legislations by reference to the International Covenant on Civil and Political Rights gained strong resistance from several states. ${ }^{106}$

Notwithstanding the foregoing, the need for better human rights protection in Australia persists. At least, three major rights issues are worth pointing out. First, there has been a growing number of legislations passed by the Parliament that infringe basic freedoms. In a survey identifying current federal and state laws, George Williams found that, up to 2015, there were 350 instances of laws that arguably encroach on essential rights and freedoms in a healthy democracy, 209 of which have been made since the terrorist attack in September 2001. ${ }^{107}$ To take one example, as shown by George Williams, s $35 \mathrm{P}$ of the ASIO Act makes it possible to imprison journalists up to 10 years for writing a story on special intelligence operation even if it is done for public interest. ${ }^{108}$ This, in turn, reinforces the inadequacy of the exclusive parliament model in preventing the Parliament from producing laws that are incompatible with human rights.

Secondly, Australia has been heavily criticised for its tough detention policy for refugees and asylum seekers who fled conflict, persecution or violence by

\footnotetext{
104 French and others, "Human Rights Protection," 24.

105 Kirby, "Protecting Human Rights," 266.

106 Ibid., 265-266.

107 George Williams, "The Legal Assault on Australian Democracy," Queensland University of Technology Law Review 16, no. 2 (2016): 37-40.

108 Ibid., 38.
} 
boat $^{109}$ despite some developments such as a dramatic decline of children being detained $^{\text {10 }}$ and a transition from indefinite detention to open centre. ${ }^{111}$ While it is true that the strong protection border policy have effectively prevented trafficking, people smuggling and even potential terrorist attacks in the future, it should be maintained that genuine asylum seekers running away from persecutions, death threats and wars in their home country should be treated with dignity. As Thomas Albrecht, UNHCR's Regional Representative in Canberra, Australia once stated "Seeking asylum is not 'illegal'. Refugees need and deserve protection and respect. The basic human right of every person to seek asylum from persecution is not diminished by their mode of arrival." ${ }_{12}$

Finally, and equally important, there is a need to entrench a nondiscrimination clause into the constitution in order to provide full recognition and rights to the Australian first people. Such need stems from stark inequality between Indigenous Australians and non-Indigenous Australians. Historically, there was a trajectory of legal policy that arguably aimed to entrench the inequality. ${ }^{13}$ As illustrated by Megan Davis, through five historical periods (frontier, protection, self-determination, practical reconciliation, and new paternalism), the legal framework at constitutional, federal and policy levels have resulted in deep inequality in the present day. ${ }^{114}$ As Indigenous peoples see it, by inserting a constitutional provision on racial non-discrimination clause would, at least, serve as an integral part of recognising the their rights. ${ }^{115}$

In a public lecture, an Australian legal academic, Hilary Charlesworth explained that the Australian great reluctance in providing a comprehensive

\footnotetext{
109 "Australia asylum: UN Criticises 'Cruel' Conditions on Nauru," BBC News, November 18, 2016, http://www.bbc. com/news/world-australia-38022204.

${ }_{110}$ Australian Human Rights Commission, "Asylum Seekers, Refugees and Human Rights," Snapshot Report 2nd Edition (2017), 14

111 Ibid., 35.

112 UNHCR Regional Representation in Canberra, "Refugees Need and Deserve Protection and Respect," UNHCR, October 31, 2016, https://www.unhcr.org/news/press/2016/10/5817bf3b//refugees-need-and-deserve-protectionand-respect.html.

${ }_{113}$ Megan Davis, "Closing the Gap in Indigenous Disadvantage: A Trajectory of Indigenous Inequality in Australia," Georgetown Journal of International Affairs 16 (2015): 35-41.

114 Ibid.

115 Ibid., 41-42.
} 
human rights protection was based upon two underlying reasons. ${ }^{.16}$ First, there has been a deep concern particularly in 1970s that the guarantee of human rights would restrain the power of states legislatures. This concern seems to have prevailed in several states such as New South Wales where the Parliamentary Committee declined not to address the systemic defect of rights protection due to parliamentary sovereignty in 2001. ${ }^{117}$ Secondly, there has been a profound belief that the Parliament is the right institution for protecting rights. It follows that conferring such authority upon the court would undermine the Australian democracy. This has been accompanied with scepticism that judges will more likely to be seduced to seize more power by using their moral understanding rather than their legal expertise in making decisions concerning human rights. ${ }^{118}$

The objections above, however, are not wholly valid. Although it is true that introducing a bill of rights in federal and sub-national jurisdictions may affect the legislative power, such as in ACT and Victoria, the notion of Parliamentary sovereignty seems rather odd. The Constitution binds both Commonwealth and States Parliaments. Their powers are either expressly or impliedly limited, thereby, they are not sovereign in any event. ${ }^{119}$ With regards to the Parliament as the best protector of rights, this contention is indefensible due to the fact that, the exclusive parliamentary model under the HRPS Act has not adequately restrained the responsible government from making laws that infringe human rights as I have demonstrated. Further, the view of describing an introduction of a bill of rights in the constitution as anti-democratic is rather old-fashioned because there already exists a partial bill of rights in the Constitution which is just extremely narrow. ${ }^{120}$ Also, the scepticism put forward by the opponent of the bill of rights is difficult to sustain as the High Court has been very cautious in construing the constitutional right provisions. This is so because, as Rosalind Dixon has argued, for most of Australian history, a majority of justices of the

\footnotetext{
${ }_{116}$ Hilary Charlesworth, "The Australian experiment with human rights charters," Law Library of Victoria Public Lecture, September 21, 2016, https://www.lawlibrary.vic.gov.au/file/385/download?token=4DCbUnHA>.

117 Kirby, "Protecting Human Rights," 266-267.

118 Charlesworth, "The Australian Experiment," 8.

119 Saunders, "The Australian Constitution," 133.

120 Dixon, "An Australian (Partial)," 82-83.
} 
High Court has been strongly committed to a form of legal conservatism, which places strong emphasis on formal legal materials and arguments. ${ }^{121}$

Another objection which could be raised to the idea of amending the Constitution to extend rights provisions comes from a view that holds that countries that have a list of extensive rights in their Constitution are not necessarily freer than those who do not such as Australia. As mentioned at the outset, the Australian Constitution has only six provisions in the Australian Constitution that are similar to UDHR provisions. Meanwhile, its neighbouring country such as Indonesia has adopted a long list of human rights under Article 28A-J in its Constitution that Tim Lindsey describes as 'lengthy and impressive, granting full range of protections extending well beyond those guaranteed in most developed states'. ${ }^{22}$ This long list of rights, however, does not guarantee the rights protection of members of religious, ethnic and sexual minority groups who have often been subject to discrimination and persecution. ${ }^{123}$ Therefore, it should be acknowledged that countries with list of rights provisions in their Constitution does not necessarily guarantee the protection of basic freedoms and human rights in practice.

It is, however, important to note that inserting rights provisions into the Constitution would grant legal protection to those who have or will be suffered from rights violation even if they are unable to access to justice and have their voice heard. By including freedom of speech and freedom of the press in the Constitution, for example, would protect individuals from the encroachment of the state on their rights to speech and to make a news story, which are healthy in a democratic society. This does not mean that every right listed in international human rights treaties should be listed in the Australian Constitution. Human rights, at best, should be seen as moral rights, or to use

${ }_{121}$ Ibid., 95 .

${ }_{122}$ Tim Lindsey, "Indonesia: devaluing Asian values, rewriting rule of law," in Asian Discourses of Rule of Law, ed. Randall Peerenboom (London: RoutledgeCurzon, 2004): 301.

${ }_{123}$ See, for example, Melissa Crouch, "Regulating Places of Worship in Indonesia: Upholding Freedom of Religion for Religious Minorities?," Singapore Journal of Legal Studies 96 (2007); Melissa Crouch, "Judicial Review and Religious Freedom: The Case of Indonesian Ahmadis," Sydney Law Review 34 (2012); Eleni Polymenopoulou, "LGBTI Rights in Indonesia: A Human Rights Perspective," Asia Pacific Journal on Human Rights and The Law 19 (2018); Leo Suryaddinata, "Ethnic Groups and the Indonesian Nation-state," in Routledge Handbook of Contemporary Indonesia, ed. Robert W. Hefner (Abingdon: Routledge, 2018). 
the word of Amartya Sen, articulations of social ethics, comparable to-but very different from-utilitarian ethics. ${ }^{24}$ Whilst it is acknowledged that the ways of advancing the ethics of human rights need not be confined only to making new laws, ${ }^{125}$ or in this case extending rights protected by the Constitution, as I have argued above, the current legal framework under the Constitution, federal and state laws does not seem adequate in protecting universal human rights. Thus, Australia would be well-advised to make an amendment to the Constitution so as to provide a better human rights protection.

\section{ADOPTING CANADIAN MODEL OF RIGHTS PROTECTION}

It is now convenient to consider what aspects of the Canadian's right protection model should be adopted by Australia. Before doing so, it is required to explain the reasons why the Canadian model is relevant to be applied in Australia. First, unlike the UK and New Zealand which share a unitary state, Australia and Canada adopt federalism. The federal principle suggests that if a national bill of rights were to be introduced, this right protection model should be applied equally to both the Commonwealth and the States. ${ }^{126}$ Secondly, Australia and Canada are both countries that have a written constitution which is difficult to amend. The Constitution outlines specific principles upon which the way the rights protection designed should be based. Finally, in Momcilovic, the High Court has reduced the opportunity for dialogue model to be applied at the Federal level. It held that a declaration of incompatibility which is one of the distinct features of the dialogue model was not an exercise of judicial power. As Robert French observed:

In any event, in the exercise of appellate jurisdiction, this Court cannot interfere with such a declaration. A declaration of inconsistent interpretation, being non-judicial and not incidental to judicial power, cannot be characterised as a judgment, decree, order or sentence of the Supreme Court falling within the appellate jurisdiction conferred upon this Court by s 73 of the Constitution. ${ }^{127}$

\footnotetext{
124 Amartya Sen, "Human Rights and the Limits of the Law," Cardozo Law Review 27 (2006): 2916.

125 Ibid., 2919.

126 Cheryl Saunders, "Protecting Rights in the Australian Federation," Adelaide Law Review 25 (2004): 207.

127 Momcilovic, 47-48.
} 
In my own view, there are at least several components that are worth considering to be adopted by Australia. First, an entrenched bill of rights in the Constitution. In 1982, Canada adopted a Charter of Rights and Freedoms after experimenting with a national bill of rights in 1962 which was widely considered to be ineffectual. ${ }^{128}$ The Charter guarantees various rights and freedoms including fundamental freedoms, democratic rights, mobility rights, legal rights, equality rights, and language rights, ${ }^{129}$ which are arguably similar to civil and political rights. As to the type of rights that might be incorporated into the Australian Constitution, I would suggest civil and political rights comparable to those listed in the ICCPR. In addition, prohibiting discrimination on the basis of gender and sexual preference in all circumstances would be a major advance for universal human rights.

Secondly, and equally important, a full recognition of status and rights of the Indigenous people. In s35 of the Charter, the status and rights of the Aboriginal people in Canada is expressly recognised. ${ }^{30}$ Additionally, the Prime Minister of Canada is required to hear the representative of the Aboriginal people in the process of amending the constitution. ${ }^{131}$ Australia can adopt these provisions to some extent in order to close the inequality gap between Indigenous Australians and non-Indigenous Australians. It has been shown that throughout history the Australian legal frameworks have perpetuated the inequality suffered by the Indigenous people. ${ }^{132}$ As such, the constitutional recognition of status and rights of the first Australian peoples would be a major breakthrough.

Thirdly, the notwithstanding clause which allows the legislation to override the constitutional rights for a five-year period. ${ }^{133}$ In Canada, this particular clause can be triggered by the Parliament as well as the legislature of the province by making a declaration that the legislation overrides protected rights in the Charter. This clause appears to seek an appropriate balance between the rights

128 Saunders, "The Australian Constitution," 130.

129 The Constitution Act 1982 being Schedule B to the Canada Act 1982 (UK), 1982, c 11-part I.

130 The Constitution Act 1982, 535 .

131 Ibid.

132 Davis, "Closing the Gap," 35-42.

133 The Constitution Act 1982, 533. 
protection and the Parliament authority. In the Australian context, the notion of the notwithstanding clause would be relevant to consider if there were an initiative to extend broader rights in the Constitution. This is so mainly because there is a strong opposition against judicial review on the basis of parliamentary sovereignty that has gained popularity. ${ }^{134}$ Although judicial review has been exercised for a century, ${ }^{135}$ meaning that such opposition does not seem to be a pertinent issue, adopting the notwithstanding clause would reconcile the authority of Parliament and the need for judicial review of laws that infringe the rights protected in the Constitution.

\section{CONCLUSION}

Australia has been widely known as one of the founding members of the United Nations. Indeed, the Universal Declaration of Human Rights was adopted when Dr Herbert Vere Evatt, a former judge of the High Court became the President of the United Nations General Assembly. ${ }^{136}$ It is not surprising then that Australia has also ratified a number of important international treaties concerning human rights. But nevertheless, when it comes to the domestic rights protection, it does not seem to be in harmony with international standards. As this paper has suggested, while a bill of rights has been adopted in some States, it is difficult to sustain that the current protection regime under the Constitution, Federal laws, and the HRPS Act is effective in safeguarding human rights.

In many cases, there is a real need for extending the rights protected by the Constitution. It is also acknowledged that constitutional change is notoriously difficult. But it would not be impossible to achieve if the wider public came to grips with a view that the Constitution and the HRPA Act provide very limited rights protection, leaving vulnerable peoples at risk of human rights abuses without any significant remedies. Moreover, it is argued that instead of opting

${ }^{134}$ Jeremy Waldron, "The Core of the Case against Judicial Review," Yale Law Journal 115(6) (2006).

135 Adrienne Stone, "Disagreement and an Australian Bill of Rights," Melbourne University Law Review 26, no. 2 (2002): 495-496.

${ }^{136}$ Australia and the Universal Declaration on Human Rights, Australian Human Rights Commission, https://www. humanrights.gov.au/publications/australia-and-universal-declaration-human-rights. 
for dialogue model, Australia should adopt the Canadian's right protection model. Some elements that are worth considering include an entrenched bill of rights, a recognition of the first Australians people and their rights, and the notwithstanding clause. Not only will it provide a more effective framework for safeguarding human rights, but it will also strike a balance between the judiciary and the legislature.

\section{BIBLIOGRAPHY}

Age Discrimination Act 2004 (Cth).

Allan, James. "The Three Rs of Recent Australian Judicial Activism: Roach, Rowe and (No)Riginalism." Melbourne University Law Review 36, no. 2 (2012): $743^{-7} 82$.

Allan, James. "The Victorian Charter of Human Rights and Responsibilities: Exegesis and Criticism." Melbourne University Law Review 30, no. 3 (2006): 906-22.

Australian Constitution.

Australian Human Rights Commission. "Australia and the Universal Declaration on Human Rights." Last accessed February 15, 2019, https://www.humanrights. gov.au/publications/australia-and-universal-declaration-human-rights.

Australian Human Rights Commission. "Functions of the Australian Human Rights Commission.” Last accessed February 15, 2019, https://www. humanrights.gov.au/about/functions-australian-human-rights-commission.

Australian Human Rights Commission. "History of the Commission." Last accessed February 15, 2019, https://www.humanrights.gov.au/about/whatare-human-rights/history-commission.

BBC News. "Australia asylum: UN criticises 'cruel' conditions on Nauru." November 18, 2016, http://www.bbc.com/news/world-australia-38022204.

Beck, Colin J et al. "Constitutions in World Society: A New Measure of Human Rights.” (January 2017): 1-29, http://dx.doi.org/10.2139/ssrn.2906946. 
Betfair Pty Limited v Western Australia (2008) 234 CLR 418.

Canada Act 1982 (UK).

Charlesworth, Hilary. "The Australian experiment with human rights charters," Law Library of Victoria Public Lecture, September 21, 2016: 1-9, https://www. lawlibrary.vic.gov.au/file/385/download?token=4DCbUnHA.

Charter of Human Rights and Responsibilities Act 2006 (Vic).

Chong, Fiona. "Human rights vs the High Court: how far can a Charter go?"Analysis \& Policy Observatory, November 23, 2011, http://apo.org.au/ node/27269.

Coast Islands Declaratory Act 1985 (Qld).

Crennan, Susan. "Magna Carta, Common Law Values and the Constitution.” Melbourne University Law Review 39, no. 1 (2015): 331-345.

Crouch, Melissa. "Judicial Review and Religious Freedom: The Case of Indonesian Ahmadis." Sydney Law Review 34 (2012): 545-572.

Crouch, Melissa. "Regulating Places of Worship in Indonesia: Upholding Freedom of Religion for Religious Minorities?" Singapore Journal of Legal Studies 96 (2007): 96-116.

Disability Discrimination Act 1992 (Cth).

Dowal v Murray (1978) 143 CLR 410.

Davis, Megan. "Closing the Gap in Indigenous Disadvantage: A Trajectory of Indigenous Inequality in Australia." Georgetown Journal of International Affairs 16 (2015): 34-44.

Dixon, Rosalind. “An Australian (Partial) Bill of Rights.” International Journal of Constitutional Law 14, no. 1 (January 2016): 80-98.

French, Robert. "Protecting Human Rights Without a Bill of Rights." The John Marshall Law Review 43, no. 3 (Spring 2010): 769-793.

French, Robert and others. "Human Rights Protection in Australia and the United Kingdom: Contrasts and Comparisons." Brief 42, no. 2 (2015): 1-29. 
Hocking, Barbara. "Aboriginal Law Does Now Run in Australia-Reflections on the Mabo Case: From Cooper v. Stuart through Milirrpum to Mabo." Sydney Law Review 15 (1993): 187-205.

Human Rights Act 2004 (ACT).

Human Rights (Parliamentary Scrutiny) Act 2011 (Cth).

Irving, Helen. "The High Court of Australia kills dialogue model of human rights." The Australian, September 16, 2011, http://www.theaustralian.com. au/business/legal-affairs/high-court-kills-dialogue-model-of-human-rights/ news-story/4aadie8e57fb5cdd7ba265a64c540f5o.

Kable v Director of Public Prosecutions (NSW) (1996) 189 CLR 51.

Kirby, Michael. "Protecting Human Rights in Australia without a Charter." Commonwealth Law Bulletin 37, no. 2 (June 2011): 255-280.

McGinty, Jim. "A Human Rights Act for Australia." The University of Notre Dame Australia Law Review 12 (Dec 2010): 1-32.

Land Act 1962 (Qld).

Lange v Australian Broadcasting Corporation (1997) 189 CLR 520.

Lindsey, Tim. "Indonesia: devaluing Asian values, rewriting rule of law." In Asian Discourses of Rule of Law, edited by Randall Peerenboom. London: RoutledgeCurzon, 2004.

Mabo v Queensland (1988) 166 CLR 186.

Mabo v Queensland [No 2] (1992) 175 CLR 1.

Meagher, Dan R. "The Human Rights (Parliamentary Scrutiny) Act 2011 (Cth) and the Courts." Federal Law Review 42, no. 1 (2014): 1-25.

Milirrpum v Nabalco Pty. Ltd (1971) 17 F.L.R 14.

Minister of Army v Dalziel (1944) 68 CLR 261.

Momcilovic v The Queen (2011) 245 CLR 1.

NFSA Films. "Admission Impossible." Filmed in 1992 in Australia, 54:22, https:// www.youtube.com/watch?v=uPfJRetYPo4. 
Polymenopoulou, Eleni. "LGBTI Rights in Indonesia: A Human Rights Perspective." Asia Pacific Journal on Human Rights and The Law 19 (2018): 1-19.

Racial Discrimination Act 1975 (Cth).

Rajanayagam, Shawn. "Does Parliament Do Enough: Evaluating Statements of Compatibility under the Human Rights (Parliamentary Scrutiny) Act." University of New South Wales Law Journal 38, no. 3 (2015): 1046-1077.

Roach v Electoral Commissioner (2007) 233 CLR 162.

Saunders, Cheryl. "Protecting Rights in the Australian Federation." Adelaide Law Review 25 (2004): 177-210.

Saunders, Cheryl. "The Australian Constitution and Our Rights." Future Justice (Sydney: Future Leaders, 2010): 117-135.

Sen, Amartya. "Human Rights and the Limits of the Law." Cardozo Law Review 27 (2006): 2913-2927.

Sex Discrimination Act 1984 (Cth).

Stone, Adrienne. "Australia's Constitutional Rights and the Problem of Interpretive Disagreement." Sydney Law Review 27, no. 1 (2005): 29-48.

Stone, Adrienne. "Disagreement and an Australian Bill of Rights." (2002) Melbourne University Law Review 26, no. 2 (2002): 478-497.

Suryadinata, Leo. "Ethnic Groups and the Indonesian Nation-state." In Routledge Handbook of Contemporary Indonesia, edited by Robert W. Hefner. Abingdon: Routledge, 2018.

UNHCR. "Refugees need and deserve protection and respect." Last accessed October 20, 2019, https://www.unhcr.org/news/press/2016/10/5817bf3b4/ refugees-need-and-deserve-protection-and-respect.html.

Waldron, Jeremy. "The Core of the Case against Judicial Review." Yale Law Journal 115, no. 6 (2006): 1346-1406. 
Watchirs, Helen and Gabrielle McKinnon. "Five Years' Experience of the Human Rights Act 2004 (ACT): Insights for Human Rights Protection in Australia." UNSW Law Journal 33, no. 1 (2010): 136-170.

Williams, George. "The Legal Assault on Australian Democracy." Queensland UT Law Review 16, no. 2 (2016): 19-41.

Williams, George. "The Victorian Charter of Human Rights and Responsibilities: Origins and Scope." Melbourne University Law Review 30, no. 3 (2006): 880-905.

Williams, George and Daniel Reynolds. "The Operation and Impact of Australia's Parliamentary Scrutiny Regime for Human Rights." Monash University Law Review 41, no. 2 (2016): 469-507.

Williams, George and Lisa Burton. "Australia's Exclusive Parliamentary Model of Rights Protection." Statute Law Review 34, no. 1 (2013): 58-94. 